What Does Aid to Africa Finance?

\section{Shantayanan Devarajan}

Andrew Sunil Rajkumar

Vinaya Swaroop
The development community seems to have swung from a denial that aid is fungible to a belief that all aid is fungible. The facts seem to indicate that aid to Africa is partly fungible. Donors should therefore be concerned abcut the quality of public spending programs in recipient countries.

The World Bank

Development Research Group

Public Economics

March 1999

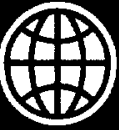


Policy Resfarch Working Paper 2092

\section{Summary findings}

If a donor gives aid for a project that the recipient government would have undertaken anyway, the aid finances expenditures other than the intended project. The notion that aid in this sense may be "fungible" has recently received empirical support.

Devarajan, Rajkumar, and Swaroop look at why aid is fungible or nonfungible, and the extent to which it is fungible in Sub-Saharan Africa.

Their results suggest that aid may be partially fungible in Africa and suggest some reasons.

They find relatively little evidence that aid leads to greater tax relief in Africa. Every dollar of aid leads to a 90-cent increase in government spending.

The implications of this result are by no means clear. If the marginal cost of taxation is exceptionally high which it might be in African countries - using aid for tax relief may be the best use of foreign resources.

Aid's effect on the composition of current and capital spending? They increase equally. Even if all aid were intended to finance capital spending, the reallocation to current spending might not necessarily be harmful.
The fungibility of loans to specific sectors generally mirrors patterns found in a broader sample of countries.

Aid to energy, transport, and communication sectors increases public spending in those sectors somewhat but by no means one for one. (By contrast, in the worldwide sample, aid to transport and communications was almost fully nonfungible.)

Aid to the education sector - which had no discernible effect on education spending in the global sample - had an almost one-for-one effect on education spending in Africa.

Even in these partially fungible sectors, governments spend more out of aid resources than they do out of their own resources, at the margin. Governments do not spend all sectoral aid in that sector - nor do they treat such aid as merely budgetary support.

The more donors to a country, the more likely aid is to be fungible. If the number of donors represents a proxy for monitoring costs, it is not surprising that most aid is partly fungible.

This paper - a product of Public Economics, Development Research Group - is part of a larger effort in the group to study the effects of aid as public expenditure. Copies of the paper are available free from the World Bank, $1818 \mathrm{H}$ Street NW, Washington DC 20433. Please contact Cynthia Bernardo, room MC2-501, telephone 202-473-1148, fax 202-522-1154, Internet address cbernardo@worldbank.org. Policy Research Working Papers are also posted on the Web at http://www. worldbank.org/html/dec/Publications/Workpapers/home.html. Shantayanan Devarajan may be contacted at sdevarajan @worldbank.org. March 1999. (34 pages)

The Policy Research Working Paper Series disseminates the findings of work in progress to encourage the exchange of ideas about development issues. An objective of the series is to get the findings out quickly, even if the presentations are less than fully polished. The papers carry the names of the authors and should be cited accordingly. The findings, interpretations, and conclusions expressed in this paper are entirely those of the authors. They do not necessarily represent the view of the World Bank, its Executive Directors, or the countries they represent. 


\title{
What Does Aid to Africa Finance?
}

\author{
Shantayanan Devarajan, Andrew Sunil Rajkumar, and Vinaya Swaroop
}

Development Research Group
The World Bank
Washington, D.C. 20433, USA

Key Words: Foreign aid, fungibility, developing countries, public expenditure, Sub-Saharan Africa.

JEL Classification: E62; $\mathrm{O} 23$

Send correspondence to: Shantayanan Devarajan, Room MC2-509, Development Research Group, World Bank, 1818 H Street, NW, Washington, D.C. 20433, USA.

Internet: SDEVARAJAN@WORLDBANK.ORG

The authors acknowledge helpful comments they received from Alan Gelb, Rino Schiavo-Campo, Howard Pack, Lant Pritchett, and seminar participants at AERC, IFPRI and the World Bank. 


\section{Introduction}

Suppose an aid donor gives money to build a primary school in a poor country. If the recipient government would have built the school anyway, then the consequence of the aid is to release resources for the government to spend on other items. Thus, while the primary school may still get built, the aid is financing some other expenditure (or tax reduction) by the government. This could be problematic, especially from a donor's perspective, if the released resources of the government end up financing "unproductive" public expenditures.

That foreign aid is in this sense "fungible" has been recognized for a long time. In 1947, Paul Rosenstein-Rodin, then Deputy Director of the World Bank's Economics Department, noted: "When the World Bank thinks it is financing an electric power station, it is really financing a brothel." In the mid-1950s, some of the Bank's member countries asked for a revision of its policy of lending only for infrastructure because they wanted to borrow for health and education projects. The World Bank's president responded that they could finance their health and education projects with the funds that were released by the Bank's financing of infrastructure.

In light of the recent re-thinking of foreign aid, brought on by "aid fatigue" in donor nations and questions of aid's effectiveness, this paper examines the extent of aid fungibility in SubSaharan Africa. Before proceeding, we note that the two anecdotes illustrate some important aspects of fungibility. First, the question of what aid ultimately finances is interesting only if the preferences of the donor are different from those of the recipient. If they had identical preferences, then it would not matter if the aid were given to a specific project or as budgetary support. Second, when donor and recipient preferences differ, it is still not clear whether the presence of fungibility is good or bad. It all depends on what the government does with the resources that are released by the aid projects-whether it builds pyramids or health clinics. 
Third, regardless of what the government does with the released resources, aid fungibility has important implications for how donors evaluate the impact of their aid. To the extent that aid is fungible, the development impact of the electric power station loan is not captured by the rate of return of that project (Devarajan et al. [1997]).

Despite its importance to policy, the question of the fungibility of aid remained at the level of anecdotes for over four decades. Recently, however, there has been a flurry of quantitative work, triggered on the one hand by heightened concern over the effectiveness of foreign aid (Boone [1995], World Bank [1998]), and on the other hand by the availability of data (Cashel-Cordo and Craig [1990], Gang and Khan [1991], Pack and Pack [1990, 1993, 1996], Khilji and Zampelli [1994], Feyzioglu et al. [1998], Jha and Swaroop [1998]).

The recent work has shown that foreign aid is fungible in certain countries and in certain sectors. For instance, Pack and Pack find that aid is totally fungible in the Dominican Republic, non-fungible in Indonesia and partially fungible in Sri Lanka. Jha and Swaroop [1998] show that aid to India is fungible at the national level, but non-fungible at the state level. Using a panel data set, Feyzioglu et al. [1998] find that foreign aid is fungible in agriculture, education and health, partially fungible in power and non-fungible in transport and communication. None of these authors has offered an explanation for their results.

No region will be more affected by these changes than Sub-Saharan Africa, which receives three times more foreign aid per capita than other developing countries. Some of the disappointing results on the effectiveness of aid in Africa may be due to its fungibility. Yet, none of the studies on aid fungibility has focused on Africa.

The purpose of this paper is to fill these two lacunae in our understanding of the fungibility of foreign aid: why aid is fungible or non-fungible, and the extent of aid fungibility in Africa. In 
section 2 , we present a model of aid fungibility. In section 3 , we estimate the model using data from Africa. Our estimates permit us to compare the extent of aid fungibility in Africa with respect to other countries, as well as identify some of the reasons why aid may or may not be fungible in Africa. Section 4 presents some concluding remarks about the implications of our results for policy and future research.

\section{A Model of Semi-fungible Aid}

In this section, we present a simple model that illuminates why aid may or may not be fungible. A variant of the models in Pack and Pack [1993] and Feyzioglu et al. [1998], the model incorporates the essential element in any discussion about fungibility, namely, a difference in the objective functions of the recipient and donor. Consider, therefore, an aid recipient with an objective function over two types of expenditure, $g_{1}$ and $g_{2}$, and domestic revenue $R$. In the absence of aid, the recipient's problem is to maximize

$$
\begin{aligned}
& U\left(g_{1}, g_{2}\right)=g_{1}{ }^{\alpha} g_{2}^{1-\alpha} \text { subject to } \\
& R=p_{1} g_{1}+p_{2} g_{2} .
\end{aligned}
$$

The recipient's problem gives rise to the standard optimal solutions, $g_{1}{ }^{*}$ and $g_{2}{ }^{*}$. Now suppose the donor has a different objective function over the recipient's expenditure on $g_{1}$ and $g_{2}$ :

$$
U\left(g_{1}, g_{2}\right)=g_{1}^{\beta} g_{2}^{1-\beta} \quad \text { with } \beta>\alpha>0 .
$$

Thus, the donor would like the recipient to spend more on good 1 than the recipient would otherwise. For example, good 1 could be education, which the donor has targeted as a priority sector. The donor's aid policy, then, is to give the recipient $(\beta-\alpha) R$ to spend on $g_{1 .}{ }^{1}$

\footnotetext{
${ }^{1}$ As noted above, we are only modeling foreign aid in the case when there is a difference in the objective functions of the recipient and the donor. Thus, $\beta \neq \alpha$. Note that even with this aid, the recipients'
} 
Given the difference in objective functions, the recipient would like to treat this aid as budgetary support. But there are costs to treating earmarked aid as fully fungible. For instance, it could lead to a cutback in aid the following year. We assume these costs (or, equivalently, the donor's ability to monitor expenditures) are a function of the deviation between the donor's desired total expenditure on good $1, p_{1} g_{1}{ }^{* *}$, and the actual amount spent on that good. The recipient's new optimization problem, therefore, is to maximize

$$
\begin{aligned}
& U\left(g_{1}, g_{2}\right)=g_{1}{ }^{\alpha} g_{2}{ }^{1-\alpha} \text { subject to } \\
& R+(\beta-\alpha) R=p_{1} g_{1}+p_{2} g_{2}+\theta\left(p_{1} g_{1}{ }^{* *}-p_{1} g_{1}\right)
\end{aligned}
$$

where $\theta$ is the cost of treating earmarked aid as fully fungible. Although this cost is probably borne in the future (in terms of less foreign aid than would otherwise have been given), we incorporate it as a charge today by considering the present value of this future cost.

An interior solution to the above problem exists if $\theta<(\beta-\alpha) / \beta$ :

$$
p_{1} g_{1}^{*}=\frac{\alpha(1-\beta \theta)}{1-\theta} R+\frac{\alpha}{1-\theta} A I D
$$

where AID $=(\beta-\alpha) R$. If $\theta \geq(\beta-\alpha) / \beta$, the cost of treating earmarked aid as fully fungible is so prohibitively high that $\mathrm{p}_{1} \mathrm{~g}_{1}{ }^{*}=\mathrm{p}_{1} \mathrm{~g}_{1}{ }^{* *}=\alpha R+(\beta-\alpha) R$, i.e., aid is spent on $\mathrm{g}_{1}$ as desired by the donor. On the other hand, when $\theta=0$, there is no penalty for treating aid as budgetary support, so the coefficient for $R$ becomes the same as that for AID. These two scenarios are illustrated in Figure 1.

\section{[Figure 1]}

The most important feature, however, is that equation (2.1) lends itself to econometric estimation, since the variables $R$ and AID are in principle observable. By estimating a variant of 
equation (2.1), in the next section, we attempt to figure out how fungible aid is in different sectors.

Before proceeding to the empirical estimation, we treat one other issue that is often raised in discussing aid fungibility. That is the possibility that aid does not release resources for other expenditures but that it does reduce tax effort. From the reasoning of the previous section, if the aid were earmarked for some expenditure that would have taken place anyway, the recipient government could use the funds released for some other spending or to reduce the amount of taxes it collects. In fact, if the marginal cost of taxation is high, this may be a prudent strategy for the recipient. To capture this possibility, we rewrite the recipient's utility function as

$$
U\left(g_{1}, g_{2}, 1-R\right)
$$

where the $(1-R)$ term represents the share of gross domestic product (GDP) available to the private sector. The recipient's problem now is to maximize

$$
\begin{aligned}
& \quad U\left(g_{1}, g_{2}, 1-R\right)=g_{1}{ }^{\alpha_{1}} g_{2}{ }^{\alpha_{2}}(1-R)^{\alpha_{3}} \text { subject to } \\
& R=p_{1} g_{1}+p_{2} g_{2} .
\end{aligned}
$$

The first-order conditions to this problem yield $R=1-\alpha_{3}$. When the country receives aid in the amount $a$ (assume it is intended for budgetary support), the solution to the new maximization problem yields $R=1-\alpha_{3}-\alpha_{3} a$. Thus, the amount of aid that is diverted for reducing tax effort will be a function of the relative weight of the tax distortion $\left(\alpha_{3}\right)$ compared with the productivity of the other two expenditures in the utility function. In short, the recipient has the same incentive to divert aid toward tax reduction as towards other expenditures: the amount of diversion depends on the productivity of expenditures and the costs of taxation.

here is the fact that we observe aid directed at particular sectors, that is, projects. 
The above model describes fairly closely the situation of several African countries. In the past several decades, Sub-Saharan Africa has received more foreign aid—both in gross as well as net terms-than any other region. Between 1970 and 1995, average per capita aid to all SubSaharan African countries was US\$23 (measured in current dollars); the average for all other developing countries was less than US\$8. A number of studies have documented the aid experience of Africa. ${ }^{2}$ In analyzing the growth performance of Sub-Saharan Africa, Easterly and Levine [1993] looked at, among other variables, the impact of external income. Their main finding was that an annual increase in external income-from better terms of trade and transfers (grants and loans)-equal to 1 percentage point of GDP raises growth by 0.6 percentage points. Helleiner [1992] and Demery and Husain [1993] have argued that during the 1980s foreign aid to Sub-Saharan Africa financed real imports and aid was instrumental in allowing several countries to move out of the import-compression phase. Were aid flows to Africa financing expenditures that would otherwise not be made? Were aid-financed imports truly marginal? Has aid to SubSaharan Africa been fungible? If so, why, and if not, why not? These are the issues to which we now turn.

\section{Empirical Analysis}

The model in section 2 develops links between foreign aid and fiscal variables. In our empirical analysis, we examine these links. Using a panel database from 18 Sub-Saharan African countries (more on this below), we first estimate the statistical relationship between foreign assistance, measured in gross terms, and total public spending. To determine which expenditure items were funded by foreign aid, we examine the link between total foreign aid and various public-spending activities. The impact of earmarked sector-specific aid on sectoral spending is

\footnotetext{
${ }^{2}$ See World Bank [1994] for a review.
} 
estimated next. Finally, we examine whether the "fungibility coefficient" is affected by donors" monitoring costs. Specifically, we assess whether the number of aid donors in a particular country - a proxy for monitoring costs-affects the fungibility analysis.

\subsection{Empirical research on aid fungibility}

Empirical research on the fungibility of aid has been done in individual countries using timeseries data. Gang and Khan [1991], Gupta [1993], Jha and Swaroop [1998], McGuire [1978], Pack and Pack [1990, 1993, 1996], among others, have analyzed aid fungibility across the sectoral classification of expenditures. In a study of foreign aid to Indonesia, Pack and Pack [1990] did not find any evidence of fungibility across sectoral expenditures. On the other hand, in the Dominican Republic they (Pack and Pack [1993]) found evidence of substantial diversion of foreign aid away from its intended purposes. The main innovation in Jha and Swaroop [1998] is to incorporate the intergovernmental fiscal link in examining economic fungibility of external assistance in India. Using data on India, a federal country, they find that external assistance intended for development purposes merely substitutes for spending that governments--central and states-would have undertaken anyway; the funds freed by aid are spent on nondevelopment activities in general and administrative services in particular. Moreover, in passing external assistance to states, the central government makes a reduction in other transfers to states.

The individual country studies, while important, do not allow any cross-country generalization, which could be useful information to the donor community. The study by Feyzioglu et al. [1998] uses a cross-country panel data set to analyze the relationship between sector-specific foreign aid and government expenditure on the agriculture, defense, education, energy, health, and transport/communications sectors. They find that developing country 
governments receiving earmarked concessionary loans for agriculture, education and energy, reduce their own resources going to these sectors and use it elsewhere; only loans to the transport and communication sector are fully spent on purposes intended by donors. There are a few other cross-country studies that have analyzed the issue of fungibility. Cashel-Cordo and Craig [1990] used a sample of 46 developing countries to analyze whether or not foreign aid changes the composition of government expenditure. The expenditure components in their analysis are, however, limited to defense and nondefense spending. The study by Khilji and Zampelli [1994] also looks at defense and nondefense expenditures in examining the fungibility of U.S. aid among eight major aid recipient countries.

\subsection{Data, choice of variables and sample statistics}

Our empirical analysis is based on a panel database that has annual observations on 18 SubSaharan African countries from 1971 to 1995 . The countries included in the sample are: Botswana, Burkina Faso, Cameroon, Ethiopia, Ghana, The Gambia, Kenya, Liberia, Lesotho, Madagascar, Malawi, Mauritius, Nigeria, Sudan, Swaziland, Zaire, Zambia, and Zimbabwe. The sample choice-number of countries and time period-was based on data availability for all the relevant variables, subject to the constraint that at least 10 years of complete data had to be available for each country in the sample. (For more information on the sample selection method and data sources, see the Data Appendix.) The panel data are organized along three dimensions:

(i) foreign aid variables; (ii) fiscal variables (public spending and revenue); and (iii) income and control variables.

(i) Foreign aid data. Our main aid variable is the total annual gross disbursement of Official Development Assistance (ODA) by all bilateral and multilateral sources, reported in an aid 
publication of the Organisation of Economic Co-operation and Development (OECD). ODA has two components: grants and concessionary loans. To examine the impact of sector specific aid on sectoral spending, we had to use concessionary loans as the aid variable since no sectorspecific information on grants is available. The data on sector-specific concessionary loans are available from the World Bank database. Data on total aid were also used to derive the variable we used as a proxy for the level of monitoring exerted on aid recipients.

(ii) Fiscal data. Our main source of fiscal data (public spending and revenue) is the International Monetary Fund's (IMF) database on Government Finance Statistics. In the definition of total public spending, we have included principal payments on concessionary loans. This adjustment was made because we were interested in finding out how much, if at all, aid was being used to finance principal payments due on past loans. For this reason, we also measure foreign aid in gross (as opposed to net) terms though we do not know if part of the aid was given for debt rescheduling or was an untied budgetary support. In terms of the composition of public spending we collected data for our sample countries on current, capital, and loan repayments on the one hand, and sectoral (agriculture, education, energy, health, industry, transport and communication) spending on the other. We were also interested in finding out if any of the aid money was channeled towards interest payments on foreign debt. We therefore obtained information on this variable for each country from the OECD database.

(iii) Data on income and control variables. The database includes data on GDP, infant mortality, gross primary and secondary school enrollment rates, population and the share of agriculture in national income.

Table 1 shows the summary statistics for the 18-country sample. Measured in 1995 U.S. dollars the mean per capita GDP over the period 1970 through 1995 is US\$837. Over this period, 
the cross-country means range from a low of $\$ 178$ (Ethiopia) to $\$ 1,951$ (Mauritius).

\section{[Table 1]}

The mean size of government (measured as the share of total government spending in GDP) in these countries is close to 28 percent. Once again we see a large variation in terms of crosscountry means: The range is from 11.2 percent for Burkina Faso to 52.7 percent for Lesotho. The average share of foreign aid in GDP for this group of Sub-Saharan African countries is 10 percent. Nigeria, a major oil producer and exporter, is at the lower end ( 0.2 percent of GDP). When aid is measured as a percentage of GDP, The Gambia is the largest recipient. However, in per capita terms, Botswana is the country in the sample that received the highest foreign aid. Finally, roughly two-thirds of total aid is in the form of grants for this group of countries.

Figures 2 and 3 show the sectoral breakdown of concessionary loans and government expenditure, respectively. ${ }^{3}$ Almost 40 percent of the concessionary loans have gone to four sectors: agriculture, energy, industry, and transport and communications. It is clear from the figure that there were not too many concessional loans to education and health. ${ }^{4}$ Among the six sectors, education accounts for most of the public spending. Next are transport and communication and agriculture. As a crude indicator, these figures signal that donor and recipient preferences may not be identical.

\section{[Figures 2 and 3]}

\subsection{Regression analysis}

Foreign aid fungibility is analyzed by estimating the following three equations:

\footnotetext{
${ }^{3}$ Concessionary loans to "other" sectors includes multisector loans, balance of payments support, administrative budget support, and loans to sectors that cannot be identified.

${ }^{4}$ It is possible that a lot of assistance was given to education and health sectors in the form of grants. Lack of data precludes us from analyzing the composition of grants.
} 


$$
\begin{aligned}
& G_{i, t}=\alpha_{0, i}+\alpha_{1} \operatorname{Aid}_{i, t}+\alpha_{2} G D P_{i, t-1}+\varepsilon_{i, t} \\
& \text { for country i }(i=1, \ldots, I) \text { at time } t(t=1, \ldots, T) \\
& G_{i, t}^{E_{i}}=\delta_{0, i}+\delta_{1} G D P_{i, t-1}+\delta_{2} \operatorname{Aid}_{i, t}+\delta_{3}\left(G_{i, t}^{N}-G_{i, t}^{N}\right)+v_{i, t}
\end{aligned}
$$

where $E_{j}\{j=1,2,3\}$ are current, capital and principal repayment expenditures and $G^{N}$ is total domestic resources defined as total expenditures net of foreign aid. $G_{i, t}^{N}$ is estimated as

$$
\hat{G}_{i, t}^{N}=\beta_{0, i}+\beta_{1} A i d_{i, t}+\beta_{2} G D P_{i, t-1}
$$

This two-stage estimation procedure is used because foreign aid affects the composition of public spending directly as well as indirectly (more on this below). Similarly, for each sector $s$ ( $s$ $=1, \ldots, S)$ we have:

$$
\begin{aligned}
G_{i, s, t}=\lambda_{0, i, s}+\lambda_{1, s} G D P_{i, t-1} & +\lambda_{2, s} \text { Cloan }_{i, s, t}+\lambda_{3, s}\left(G_{i, s, t}^{N}-\hat{G}_{i, s, t}^{N}\right)+\lambda_{4, s}\left(\text { Tloan }_{i, t}-\text { Cloan }_{i, s, t}\right) \\
& +\lambda_{5, s} \operatorname{TGrants}_{i, t}+\eta_{i, s, t}
\end{aligned}
$$

where $G_{i, s, t}^{N}$ is estimated as:

$$
\begin{aligned}
\hat{G}_{i, s i t}^{N}= & \phi_{0, i, s}+\phi_{1, s} G D P_{i, t-1}+\phi_{2, s} \text { Cloan }_{i, s, t}+\phi_{3, s}\left(\operatorname{Tloan}_{i, t}-\text { Cloan }_{i, s, t}\right) \\
& +\phi_{4, s} \text { TGrants }_{i, t}
\end{aligned}
$$

Eq. (3.1) examines the impact of total foreign aid on the government's budget. This model incorporates the possibility that if the aid was earmarked for some expenditure that would have taken place anyway, the recipient government could use the funds released for some other spending or to reduce the amount of taxes it collects.

In section 2, we derived the condition that links public spending on good $i$ with domestic revenue $R$ and foreign aid (for example, see eq. 2.1). Equations (3.2) and (3.3) estimate this relationship for various types of public expenditure. However, we know that domestic resources 
may change with a change in foreign aid. Since we are interested in the effects on public expenditure of domestic resources and foreign aid, independently of each other, we control for the impact of aid on total domestic resources. This is done using a two-stage estimation process. Eq. (3.2') indicates the first stage estimation for capital and current expenditure, and for principal repayments. The residuals from eq. (3.2') are then used in place of in eq. (3.2), which is the second-stage estimation. Similarly, the residuals from eq. (3.3') are used in place of $\mathrm{G}^{\mathrm{N}}$ in eq. (3.3), which estimates the impact of sector aid and domestic resources on sector expenditure.

The variables in the above mentioned three regressions are (all measured in 1995 US\$, per capita terms):

$\mathrm{GDP}_{\mathrm{i}, \mathrm{t}} \quad$ Gross domestic product for country $i$ at time $t$

$\mathrm{G}_{\mathrm{i}, \mathrm{t}}: \quad$ Total government expenditure

$\mathrm{G}_{\mathrm{i}, \mathrm{t}}{ }^{\mathrm{N}}$ : $\quad$ Total government expenditure (net of foreign aid)

$\mathrm{G}_{\mathrm{i}, \mathrm{t}}{ }^{\mathrm{Ej}}$ : Government expenditure for current, capital or principal repayment purposes, where $E_{j}\{j=1,2,3\}$ is current, capital or principal repayment expenditure, respectively

$\mathrm{G}_{\mathrm{i}, \mathrm{s}, \mathrm{t}}: \quad$ Government expenditure in sector $s$

Aidi, $_{\mathrm{i}, \mathrm{t}}$ : Total gross ODA disbursement

CLoan $_{\mathrm{i}, \mathrm{s}, \mathrm{t}}$ : $\quad$ Gross concessionary loan disbursement to sector $s$

TLoan $_{\mathrm{i}, \mathrm{t}}$ : $\quad$ Total concessionary loans to all sectors

TGrants $\mathrm{i}_{\mathrm{i}, \mathrm{t}}$ : $\quad$ Total grants to all sectors

$\varepsilon \mathrm{i}, \mathrm{t}, \mathrm{v}_{\mathrm{i}, \mathrm{t}} \& \eta_{\mathrm{i}, \mathrm{s}, \mathrm{t}}: \quad$ White noise error terms for the three equations.

We would ideally like to include sector-specific grants in equation (3.3). However, data on grant disbursements are available only at the aggregate level, and not by sector (see subsection 3.2 above). Thus we have to use concessionary loans as our sector-aid variable.

Loans to a particular sector may be correlated with loans to other sectors and with grants. To avoid bias in our estimates, we include the latter as additional right-hand-side variables in eqs. $\left(3.3^{\prime}\right)$ and (3.3), although these are not the variable coefficients we are primarily interested in. 
Table 2 presents the estimates of eqs. (3.1), (3.2) and (3.2') which are all estimated under the null hypothesis that the coefficient of the country dummy variable, $\alpha_{0,1}$, is a fixed parameter. If, however, the Hausman test rejects the null hypothesis that the appropriate model is fixed effects then the random effects model is estimated. ${ }^{5}$

\section{[Table 2]}

Regression (2.1) shows a positive and statistically significant relationship between total public spending and the total gross disbursement of ODA. The regression shows that a dollar increase in foreign aid leads to an increase of 0.89 cents in total government spending; the remaining aid is used for tax relief. ${ }^{6}$ Moreover, a dollar increase in last year's GDP leads to an increase of 11 cents in government expenditures. This evidence suggests that in this sample of 18 Sub-Saharan African countries, very little aid, if any, is being used for tax relief. At the margin, most aid is associated-in a statistical sense-with an increase in government spending.

Regression (2.2) is estimated to control for the effect of foreign aid and GDP on the domestic resources of the government. The residuals of this equation are used as an exogenous variable in the subsequent equations reported in this table. In turn, this variable represents the true exogenous shock to a country's domestic resources. Regression (2.3), which includes expenditure according to the economic classification of IMF's Government Financial Statistics, indicates that roughly 28 cents of an additional dollar in ODA is spent on government's capital

\footnotetext{
${ }^{5}$ In the fixed effects model, $\alpha_{0, i}$, the country dummy parameter, is a fixed coefficient. In the random effects model these parameters are assumed to be independent random variables with a fixed mean and variance, i.e., $\alpha_{0, i}=\alpha_{0}+\varepsilon_{i}$. Hausman has developed a test, which shows that under the null hypothesis the fixed effects model is appropriate and the preferred estimator is least squares with dummy variables. If, however, the fixed effects model is rejected in favor of the random effects model then the preferred estimator is generalized least squares. For details, see Hausman [1978].

${ }^{6}$ In some developing countries, not all foreign aid goes through the budget. Our aid data (from OECD sources) are likely to be different from that of budgetary aid receipts of the Sub-Saharan African governments. It is therefore possible that some of the other 11 cents of the marginal dollar in aid represents extra-budgetary aid.
} 
expenditure. Moreover, the coefficient of ODA in regression (2.4) shows that 30 cents of the dollar increase in aid goes toward current expenditure. These findings may not be necessarily bad for at least two reasons. First, parts of foreign aid could be designed for current expenditure related activities. Second, several components of current expenditure, such as operations and maintenance, may have higher rates of return than capital expenditure. ${ }^{7}$ Finally, the aid coefficient in regression (2.5) shows that 31 cents of the marginal dollar are being used to finance principal repayments on the foreign concessionary loans. A comparison of the coefficients on the aid variable with the coefficients on the variable "residuals of total spending net of aid" suggests that at the margin more money is spent on current expenditure if the financing is from own domestic sources. For capital spending, however, the source of additional resources do not matter; be it foreign or domestic, 28 cents of an additional dollar is spent. Regression (2.5) indicates that none of the additional domestic resources is used to finance debt repayments.

Table 3 provides the estimates of the same equations as reported in table 2 except that the aid variable in these equations is broken in its two components: concessionary loans and grants. As indicated in eq. 3.1, the impact of the two aid variables on total public expenditure is remarkably identical. In their analysis of 14 developing countries (of which four were in Sub-Saharan Africa), Feyzioglu et al. [1998] found that disbursement of concessionary loans were far more stimulative of total government expenditures than was total aid. As conjectured in their paper, however, the difference in the two coefficients could be due to the bias introduced in the estimate of concessionary loans for not including data on grants. An important finding reflected in eq. 3.5 of our table 3 is that it is only grants and not loans that are used to repay the principal on loans.

\footnotetext{
${ }^{7}$ In a study of 43 developing countries over 20 years, Devarajan, Swaroop and Zou [1996] show that the only broad public expenditure category that is associated with higher economic growth is the current expenditure.
} 
Moreover, concessionary loans are used more for current than capital purposes (Regressions 3.3 and 3.4).

\section{[Table 3]}

Table 4 has the estimates of regression (3.3). Regressions reported in this table examine the link between the gross disbursement of concessionary loans to a particular sector and public spending in that sector.

\section{[Table 4]}

In each of the six sectoral regressions-one each for agriculture, energy, industry, transport and communication, education and health-the coefficient on the variable "residuals of total spending net of aid" indicates how the government distributes an additional dollar that it gets from all resources net of concessionary loans. Comparing these coefficients with the coefficients on the sectoral-aid variable (loans to sector) indicate the level of fungibility at the sectoral level. Only concessionary loans to the education, energy, and transport and communication sectors ${ }^{8}$ show a positive and statistically significant relationship with their respective sectoral spending. The regression on the energy sector shows that a dollar increase in sectoral aid leads to an increase of 13 cents in energy sector spending; the remaining aid is used elsewhere. Moreover, when governments get an extra dollar in domestic resources they only spend, on average, 1 cent on the energy sector. Comparing the two coefficients suggests that aid to the energy sector is partially fungible. Evidence from the transport and communication sector (T\&C) reveals a similar story. The increase in sectoral spending from own resources is 13 cents but it jumps to 36 cents from aid resources, thus indicating a case of partial fungibility. Aid to education, however, is being spent almost fully in the sector. Since in education, teacher wages are nearly 95 percent

\footnotetext{
${ }^{8}$ As noted at the bottom of table 4, Botswana is evidently an outlier for the education regression. The analysis in the text focuses on regression (4.7), without Botswana in the sample.
} 
of the budget, it is likely that aid finances nearly everything else at the margin. Other sectoral regressions - agriculture, health, and industry-indicate that there is no evidence from this group of countries that aid to these sectors is increasing spending in the sectors for which it was intended.

\subsection{Regression analysis: What determines the level of fungibility?}

The sector regressions in the previous section assume that the level of fungibility, which is captured by the parameter $\theta$ in equation (2.1), is the same across countries. A more realistic approach may be to allow the coefficient of the sector-aid variable in the regressions-which is positively related to $\theta$ (see equation 2.1) - to be a function of the degree of monitoring exerted by aid donors on the recipient country. Since we cannot observe this degree of monitoring, we use a proxy for it: the total number of aid donors. A donor would have greater difficulty monitoring his aid program if he is one of several donors in the country, compared with the case if he is the only donor. Given a particular level of aid to a country (for any given sector), we would expect the number of donors to be inversely correlated with the level of monitoring, and hence with the coefficient of the sector aid variable in the regressions.

To test this hypothesis, we modify equation (3.3), allowing the coefficient of our sectorspecific aid variable, $\lambda_{2, i, s, t}$, to be a linear function of the total number of aid donors to country $i$, $N d_{i, r}$ :

$$
\lambda_{2, i, s, t}=h_{0, i, s}+h_{1, s} N d_{i, t}
$$

In this flexible specification, $h_{0, i, s}$ is allowed to vary across the 18 countries. However, $h_{1, s}$ is the same for all countries (for any given sector). The parameter $h_{1, s}$ measures the relationship 
between changes in the number of donors $\left(N d_{i, t}\right)$ and changes in the coefficient of sector aid $\left(\lambda_{2, i, s, t}\right)$

Using equation (3.4) to substitute into (3.3) we get the following estimable equation:

$$
\begin{aligned}
G_{i, s, t}=\lambda_{0, i, s} & +\lambda_{\uparrow, s} G D P_{i, t-1}+\sum_{j=1}^{18} h_{0, i, s}\left(\text { CDummy }_{j} \text { Cloan }_{i, s, t}\right)+h_{1, s}\left(\text { Nd }_{i} \cdot \text { Cloans }_{i, s, t}\right) \\
& +\lambda_{s, s}\left(G_{i, s, t}^{N}-\hat{G}_{i, s, t}^{N}\right)+\lambda_{4, s}\left(\text { Tloan }_{i, t}-\text { Cloan }_{i, s, t}\right)+\lambda_{s, s} \text { TGrants }_{i, t}+\eta_{i, s, t}
\end{aligned}
$$

where CDummy ${ }_{j}$ is a country dummy for country j. ${ }^{10}$ This equation includes 19 interaction terms on the right-hand side: (i) $C$ Dummy $_{j} \times$ Cloan $_{i_{s}, t}$ (country dummy (9) concessionary loans to sector), using in turn each of the 18 country dummies; and (ii) $N d_{i, t} \times$ Cloan $_{i, s, t}$ (number of donors $\diamond$ concessionary loans to sector). The other right-hand side variables in equation (3.5) also appear in equation (3.3).

Equation (3.5) was estimated for each of the defined sectors. The key results are shown in table 5. Given the large number of regressors, we only report the estimated value (with $t$-statistic) of the coefficient we are mainly interested in, that of $N d_{i, t} \times$ Cloan $_{i, s, t}$ (number of donors concessionary loans to sector). We thus present estimates for $h_{1, s}$ in equations (3.4) and (3.5), for each sector.

There is evidence that the number of donors has an impact on the level of fungibility (i.e., that $h_{1, s}$ is different from zero), but only for the transport and communications (T\&C) and

\footnotetext{
${ }^{9}$ In equation (3.3) this coefficient only had the subscripts 2 and s. Now it is allowed to vary across countries and across time (see equation 3.4). Thus we add $i$ and $t$ as subscripts.

${ }^{10}$ The country dummies operate in the usual way: CDummy takes the value 1 for country $j$, and 0 otherwise.
} 
education sectors ${ }^{11}$. The regression results in the previous sub-section showed that: (i) aid is fully fungible $\left(\hat{\lambda}_{2, s}=0\right)$ in the agriculture, industry and health sectors, and: (ii) aid is partially fungible $\left(0<\hat{\lambda}_{2, s}<1\right)$ in the energy, transport and communications (T\&C) and education sectors. According to the results shown in table 5, the partial fungibility of aid in the T\&C and education sectors is negatively related to the number of aid donors to a recipient country. This supports our hypothesis that the number of donors has an inverse relationship with, and is a proxy for, the degree of monitoring exerted by donors, at least for the $\mathrm{T} \& \mathrm{C}$ and education sectors.

\section{[Table 5]}

\subsection{Has fungibility changed over time?}

To see if the degree of fungibility has changed over time for sector-specific aid, we again modify equation (3.3), this time allowing the coefficient $\lambda_{2, s}$ to be a function of time:

$$
\lambda_{2, s, t}=m_{0, s}+m_{1, s} t
$$

where $t=1$ for the year $1971, t=2$ for the year 1972 , and so on. (The procedure is similar to that described in the previous subsection, except that $\lambda_{2, \mathrm{~s}}$ is now a function of time, and not of the number of donors.) We now get the following estimable equation:

$$
\begin{gathered}
G_{i, s, t}=\lambda_{0, i, s}+\lambda_{1, s} G D P_{i, t-1}+m_{0, s} \text { Cloan }_{i, s, t}+m_{1, s}\left(\text { Cloans }_{i, s, t} . t\right)+\lambda_{3, s}\left(G_{i, s, t}^{N}-\hat{G}_{i, s, t}^{N}\right) \\
+\lambda_{4, s}\left(\text { Tloan }_{i, t}-\text { Cloan }_{i, s, t}\right)+\lambda_{s, s} \text { TGrants }_{i, t}+\eta_{i, s, t}
\end{gathered}
$$

The results from estimating (3.8) are shown in Table 6.

\section{[Table 6]}

\footnotetext{
${ }^{11}$ As noted at the bottom of table 4, Botswana is evidently an outlier for the education regression. The analysis in the text focuses on regression (5.7), without Botswana in the sample.
} 
The coefficient of "concessionary loans $\diamond$ time" is not statistically significant in any of the regressions. ${ }^{12}$ Hence there is no strong evidence of fungibility changing over time (i.e., there is no clear evidence of $\mathrm{m}_{1, \mathrm{~s}}$ in equation 3.7 being different from zero). In the education sector, however, there is some weak evidence of fungibility increasing over time. The coefficient of "concessionary loans to sector" in regression (4.7) from table 4 is statistically significant. But the same coefficient in regression (6.7)-which has the additional term "concessionary loans $\mathrm{x}$ time" on the right-hand side-is not. The presence of this additional term should make little difference to the regression results if indeed the true $\mathrm{m}_{1, s}$ is zero for the education sector. The fact that its introduction lowers the coefficient of "concessionary loans to sector" suggests that the true $\mathrm{m}_{1, \mathrm{~s}}$ is negative, i.e., that fungibility has increased over time. In sum, there is some evidence that fungibility has increased over time for the education sector, although it is statistically weak evidence. For the other five sectors, the data show that fungibility has not changed over time.

\section{Conclusion}

This paper set out to explore two issues: (i) the extent of aid fungibility in Sub-Saharan Africa; and (ii) reasons why aid was fungible or not. In terms of the first question, we find that the broad pattern of aid fungibility observed in cross-country and country-specific studies is reflected in our analysis of African countries. Specifically, we find relatively little evidence that aid leads to greater tax relief in Africa; every dollar of aid leads to an increase in government spending of 90 cents. We reiterate that the implications of this result are by no means clear-cut. If the marginal cost of taxation is exceptionally high-and there is some evidence that this is so in African countries (see Devarajan, et al. [1998])- then using aid for tax relief may well be the

\footnotetext{
${ }^{12}$ For the education sector, the relevant regression in table 6 is (6.7) and not (6.6). This is because Botswana is an outlier for this sector; see notes for table 4 .
} 
best use of foreign resources. The effect of aid on the composition of public spending between current and capital expenditures is also broadly consistent with international evidence. Aid in Africa leads to an increase in current and capital spending in equal amounts. Again, we note that, even if all aid was intended to finance capital expenditures, the reallocation to current spending may not necessarily be harmful. One of Africa's problems is the chronic underspending on operations and maintenance. Interestingly, we find that an almost equal amount of aid goes towards repaying the principal on past loans. On the surface, this appears to be a striking result. Very few donors would have explicitly given aid in order to repay loans. But on further reflection, this is not so surprising. The inability to meet debt-service payments threatened many African countries with a complete cut-off from foreign capital. The use of aid resources to relax this constraint could have been quite rational. Moreover, the fungibility of loans intended for particular sectors in Africa roughly mirrors a pattern found with a broader sample of countries, with some exceptions. Aid to energy and transport and communication sectors lead to some increase in public spending in those sectors, but it is by no means one-for-one. By contrast, in the worldwide sample, aid to transport and communications was almost fully nonfungible. ${ }^{13}$ Finally, aid to the education sector-which had no discernible effect on education spending in the global sample-has an almost one-for-one effect on education sector spending in Africa. In any event, even in these partially fungible sectors, governments spend more out of aid resources than they do out of their own resources at the margin. Aid to Africa is partially fungible: governments do not spend all sectoral aid in that sector, nor do they treat such aid as merely budgetary support.

Our answers to the second question shed light on the findings about partial fungibility. We find that as the number of donors to a country increases, aid is more likely to be fungible. If we

\footnotetext{
${ }^{13}$ Though nonfungibility of aid to a sector as a whole does not preclude aid fungibility within the sector.
} 
accept the notion that the number of donors represents a proxy for monitoring costs, then it is not surprising that most aid is partially fungible. Recipients are trading off the benefits of full fungibility with the costs. When these costs are low, such as when there are a large number of donors in a country, we observe greater fungibility.

The implications of these results are threefold. First, the development community seems to have swung from a denial of the existence of fungibility (with some notable exceptions) to the other extreme of accepting that all aid is fungible. The facts seem to indicate, though, that aid is partially fungible. On the one hand, this strengthens the conclusion that donors should be concerned with the quality of the overall public expenditure program of the recipient country. It also confirms the importance of donor coordination. On the other hand, our results seem to indicate that aid to particular sectors does have an influence on the composition of public spending, so that sectoral aid programs and projects, have a role to play in development assistance. Second, our preliminary findings about the influence of the number of donors on fungibility suggest that further work on the costs of fungibility to the recipient may be a fruitful area of research. Third, countries that are highly aid dependent and where aid is fungible, would be hurt most if the level of aid is reduced. This is because in the case of aid being fungible, its reduction would be equivalent to a decrease in the country's own revenue. Another issue, hitherto unstudied, is fungibility across donors: in a country, does increased aid from one donor increase or decrease aid from other donors? These issues are probably best addressed in individual country studies. But, for policy purposes, it is also useful-not to say essential-to pull these studies together into a cross-country analysis, as we have attempted here. 


\section{Data Appendix}

\section{Sample: Size and selection}

The sample used in the empirical analysis comprises 280 observations from 18 Sub-Saharan African countries, from the years 1971 to 1995 . The 18 countries are: Botswana, Burkina Faso, Cameroon, Ethiopia, Ghana, The Gambia, Kenya, Liberia, Lesotho, Madagascar, Malawi, Mauritius, Nigeria, Sudan, Swaziland, Zaire, Zambia, and Zimbabwe.

Sample size and selection were based entirely on data availability. We started by collecting all available data on the relevant variables for Sub-Saharan African countries, for the years 1971-95 (see sources listed below; 1971 is the first year and 1995 is the last year, for which sector-specific loan data is available). A country was included in the sample if it had complete information on all variables (aggregate as well as sector-specific) for at least 10 years of the chosen time period.

All aid and government expenditure/revenue variables, as well as gross domestic product, were converted to 1995 US\$. Conversion from local currency units to US\$ was done using World Bank conversion factors (which in most cases are the same as the official exchange rates reported in the International Financial Statistics of the International Monetary Fund).

\section{Data sources}

- Data on foreign aid are from Geographical Distribution of Financial Flows to Aid Recipients (OECD 1998) and from World Bank's database

- Data on principal repayments on concessionary loan and interest payments on foreign debt are from OECD (1998).

- Data on government expenditure, excepting concessionary loan repayments, are from 
Government Finance Statistics (International Monetary Fund, various years).

- Data on gross domestic product, agricultural output as a share of GDP, and exchange rates are from the World Development Indicators (World Bank); World Bank conversion factors were used for exchange rates.

- Data on infant mortality rates and gross enrollment rates in primary and secondary schools are from United Nations Social Indicators. 


\section{References}

Boone, Peter, 1995. "Politics and the effectiveness of foreign aid." London School of Economics and Center for Economic Performance.

Cashel-Cordo, P., and S. G. Craig, 1990. "The public sector impact of international resource transfers." Journal of Development Economics 32:17-42.

Demery, Lionel and Ishrat Hussain. 1993. "Assessment of the Interrelation between Adjustment Financing and Economic Performance in SPA Countries." Africa Region, World Bank. Processed.

Devarajan, Shantayanan, Vinaya Swaroop, and Heng-fu Zou. 1996. "The composition of public expenditure and economic growth." Journal of Monetary Economics 37(1996):313-44.

Devarajan, Shantayanan, Lyn Squire, and Sethaput Suthiwart-Narueput. 1997. "Beyond rate of return: Re-orienting project analysis." The World Bank Research Observer 12(1):35-46.

Devarajan, Shantayanan, Sethaput Suthiwart-Narueput, and Karen Thierfelder. 1998. "The Marginal Cost of Public Funds in Developing Countries." Development Research Group, World Bank. Processed.

Easterly, William, and Ross Levine. 1993. "Is Africa Different? Evidence from Growth Regressions." Mimeograph, Policy Research Department, World Bank.

Feyzioglu, Tarhan, Vinaya Swaroop, and Min Zhu. 1998. "A panel data analysis of the fungibility of foreign aid." The World Bank Economic Review, 12 (January): 29-58

Gang, I. N., and H. A. Khan. 1991. "Foreign aid, taxes and public investment." Journal of Development Economics 34: 355-69. 
Gupta, K. L. 1993. "Sectoral Fungibility of Foreign Aid: Evidence from India." University of Alberta, Alberta. Processed.

Hausman, J. A. 1978. "Specification Tests in Econometrics." Econometrica 46: 1251-72.

Helleiner, G. K. 1992. "The IMF, the World Bank and Africa's Adjustment and External Debt Problems: An Unofficial View," World Development 20 (June): 779-92.

International Monetary Fund. 1986. A Manual on Government Finance Statistics. Washington, D.C.

Jha, Shikha, and Vinaya Swaroop. 1998. "Fiscal Effects of Foreign Aid: A Case Study of India." Development Research Group, World Bank. Processed.

Khilji, N. M., and E. M. Zampelli. 1994. "The fungibility of U.S. military and non-military assistance and the impacts on expenditures of major aid recipients." Journal of Development Economics 43: 345-62.

McGuire, M. C. 1978. "A method for estimating the effect of a subsidy on the receiver's resource constraint: With an application to the U. S. Local governments 1964-1971." Journal of Public Economics 10: 355-69.

Organisation for Economic Co-operation and Development. 1998. Geographical Distribution of Financial Flows to Aid Recipients. CD-ROM. Paris, France.

Pack, Howard, and J. R. Pack. 1990. "Is foreign aid fungible? The case of Indonesia." Economic Journal 100: 188-94.

Pack, Howard, and J. R. Pack. 1993. "Foreign aid and the question of fungibility." Review of Economics and Statistics 75(May): 258-65.

Pack, Howard, and J. R. Pack. 1996. "Foreign aid and fiscal stress." The University of 
Pennsylvania, Philadelphia, PA. Processed.

World Bank. 1998. Assessing Aid: What Works, What Doesn't and Why. A World Bank Policy Research Report, Oxford University Press.

World Bank. Various years. World Development Indicators. Washington, D.C.

World Bank. 1994. Adjustment in Africa: Reforms, Results, and the Road Ahead. A World Bank Policy Research Report, Oxford University Press. 
Table 1: Summary Statistics

(constant per capita 1995US\$, except ratios which are in percent)

\begin{tabular}{lcccc}
\hline Variable & $\begin{array}{c}\text { Sample } \\
\text { mean }\end{array}$ & $\begin{array}{c}\text { Standard } \\
\text { deviation }\end{array}$ & $\begin{array}{c}\text { Minimum } \\
\text { [country mean] }\end{array}$ & $\begin{array}{c}\text { Maximum } \\
\text { [country mean] }\end{array}$ \\
\hline $\begin{array}{l}\text { 1. Government expenditure } \\
\text { Total expenditure }\end{array}$ & 249 & 233 & 39 (Burkina Faso) & 691 (Botswana) \\
$\quad$ Capital expenditure & 58 & 58 & 5 (Burkina Faso) & 252 (Botswana) \\
$\quad$ Current expenditure & 185 & 188 & 32 (Burkina Faso) & 525 (Botswana) \\
$\quad$ Repayments on concessionary loans & 5 & 11 & 0.50 (Zaire) & 12 (Swaziland) \\
Share of total expenditure in GDP & 27.8 & 11.8 & 11.2 (Burkina Faso) & 52.7 (Lesotho) \\
2. Foreign aid & & & & \\
Total aid & 62 & 46 & 2 (Nigeria) & 151 (Botswana) \\
$\quad$ Concessionary loans & 21 & 19 & 1 (Nigeria) & 40 (Swaziland) \\
$\quad$ Grants & 40 & 36 & 2 (Nigeria) & 119 (Botswana) \\
Share of total aid in GDP & 10.0 & 8.0 & 0.2 (Nigeria) & 20.8 (Gambia) \\
3. Gross domestic product & 837 & 627 & 178 (Ethiopia) & 1,951 (Mauritius) \\
\hline
\end{tabular}

Note: 1 . The above numbers are for our sample of 280 observations, from 18 Sub-Saharan African countries.

(See Data Appendix for more details.)

2. Foreign aid above refers to Official Development Assistance as reported by OECD. 
Table 2. Least Squares Regressions: Government Expenditure on Foreign Aid

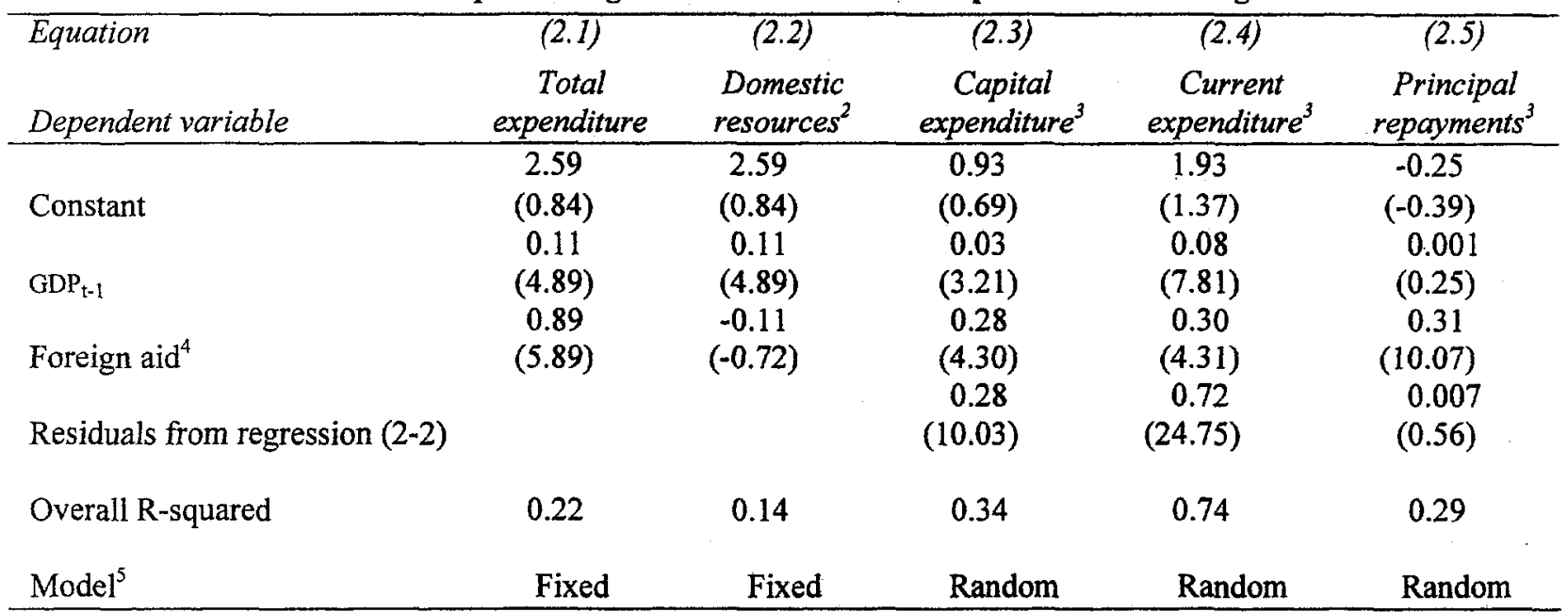

Note: 1. Before regressing, all variables were converted to constant 1995 US\$ per capita. Regressions were done in first differences based on a sample of 280 observations, from 18 countries (see Data Appendix for more details). Parentheses indicate $t$-statistics.

2. The variable "Domestic Resources" is defined as all expenditure financed from domestic resources, i.e., total expenditure minus foreign aid.

3. Total expenditure are divided into three components: capital, current, and principal repayments. The latter include only repayments on foreign concessionary loans.

4. Foreign aid is defined as Official Development Assistance (the definition used by the Organisation for Economic Co-operation and Development).

5. Model indicates whether the country dummies in the regression represent a fixed effects or a random effects model. The Hausman test statistic was used to select the appropriate model. 
Table 3. Least Squares Regressions: Government Expenditure on Concessionary Loans and Grants

\begin{tabular}{|c|c|c|c|c|c|}
\hline $\begin{array}{l}\text { Equation } \\
\text { Dependent Variable }\end{array}$ & $\begin{array}{c}\text { (3.1) } \\
\text { Total } \\
\text { expenditure }\end{array}$ & $\begin{array}{c}\text { (3.2) } \\
\text { Domestic } \\
\text { resources }\end{array}$ & $\begin{array}{c}\text { (3.3) } \\
\text { Capital } \\
\text { expenditure }\end{array}$ & $\begin{array}{c}\text { (3.4) } \\
\text { Current } \\
\text { expenditure }\end{array}$ & $\begin{array}{c}\text { (3.5) } \\
\text { Principal } \\
\text { repayments }\end{array}$ \\
\hline & 2.59 & 2.59 & 0.95 & 2.01 & -0.36 \\
\hline Constant & $(0.84)$ & $(0.84)$ & $(0.70)$ & (1.44) & $(-0.63)$ \\
\hline & 0.11 & 0.11 & 0.03 & 0.08 & 0.001 \\
\hline $\mathrm{GDP}_{\mathrm{t}-1}$ & $(4.88)$ & $(4.89)$ & $(3.21)$ & $(7.95)$ & $(0.20)$ \\
\hline & 0.89 & -0.11 & 0.32 & 0.51 & 0.06 \\
\hline Concessionary loans ${ }^{4}$ & $(3.81)$ & $(-0.44)$ & $(3.20)$ & $(4.89)$ & $(1.30)$ \\
\hline & 0.89 & -0.11 & 0.25 & 0.14 & 0.51 \\
\hline Grants $^{4}$ & $(4.42)$ & $(-0.52)$ & $(2.87)$ & $(1.54)$ & $(13.67)$ \\
\hline Residuals from regression (3-2) & & & $\begin{array}{c}0.28 \\
(10.02)\end{array}$ & $\begin{array}{c}0.72 \\
(25.07)\end{array}$ & $\begin{array}{c}0.01 \\
(0.61)\end{array}$ \\
\hline Overall R-squared & 0.22 & 0.14 & 0.34 & 0.74 & 0.43 \\
\hline Model & Fixed & Fixed & Random & Random & Random \\
\hline
\end{tabular}

Note: See table 2 for notes $1,2,3$, and 5 .

4. Official Development Assistance is the aid variable. It is subdivided into its two components: grants and concessionary loans. 
Table 4. Panel Data Regressions: Sectoral Expenditure and Concessionary Loans

\begin{tabular}{|c|c|c|c|c|c|c|c|c|c|}
\hline $\begin{array}{l}\text { Equation } \\
\text { Dependen } \\
\text { variable }\end{array}$ & (4.1) & Agriculture & Energy & Industry & $T \& C$ & Education $^{2}$ & $\begin{array}{c}\text { (4.7) } \\
\text { Education } \\
\text { without } \\
\text { Botswana }\end{array}$ & Health & Other ${ }^{3}$ \\
\hline Constant & $\begin{array}{l}2.59 \\
(0.84)\end{array}$ & $\begin{array}{l}-1.21 \\
(-0.92)\end{array}$ & $\begin{array}{c}-0.04 \\
(-0.15)\end{array}$ & $\begin{array}{l}-0.23 \\
(-0.68)\end{array}$ & $\begin{array}{l}-0.11 \\
(-0.13)\end{array}$ & $\begin{array}{c}0.26 \\
(0.17)\end{array}$ & $\begin{array}{l}3.00^{* *} \\
(2.08)\end{array}$ & $\begin{array}{l}-0.62 \\
(-1.20)\end{array}$ & $\begin{array}{l}2.41^{* *} \\
(2.30)\end{array}$ \\
\hline $\mathrm{GDP}_{\mathrm{t}-1}$ & $\begin{array}{l}0.11^{* *} \\
(4.89)\end{array}$ & $\begin{array}{c}0.01 \\
(1.33)\end{array}$ & $\begin{array}{r}0.002 \\
(1.25)\end{array}$ & $\begin{array}{r}0.004 \\
(1.61)\end{array}$ & $\begin{array}{r}0.01^{*} \\
(1.82)\end{array}$ & $\begin{array}{l}0.02 * * \\
(5.20)\end{array}$ & $\begin{array}{l}0.01 * * \\
(3.78)\end{array}$ & $\begin{array}{l}0.004^{* *} \\
(3.20)\end{array}$ & $\begin{array}{r}0.06^{*} \\
(8.27)\end{array}$ \\
\hline Foreign aid & $\begin{array}{l}0.89 * * \\
(5.87)\end{array}$ & & & & & & & & \\
\hline $\begin{array}{l}\text { Concessionary } \\
\text { loans to sector }\end{array}$ & & $\begin{array}{c}-0.04 \\
(-0.45)\end{array}$ & $\begin{array}{l}0.13^{*} \\
(1.72)\end{array}$ & $\begin{array}{c}0.11 \\
(1.57)\end{array}$ & $\begin{array}{l}0.36^{* *} \\
(2.62)\end{array}$ & $\begin{array}{l}-0.80^{* *} \\
(-2.93)\end{array}$ & $\begin{array}{l}0.98^{* *} \\
(2.10)\end{array}$ & $\begin{array}{c}0.26 \\
(0.66)\end{array}$ & $\begin{array}{l}0.65^{* *} \\
(6.50)\end{array}$ \\
\hline $\begin{array}{l}\text { Concessionary } \\
\text { loans to all other } \\
\text { sectors }\end{array}$ & & $\begin{array}{l}0.11 * * \\
(2.63)\end{array}$ & $\begin{array}{c}0.004 \\
(0.24)\end{array}$ & $\begin{array}{r}0.002 \\
(0.07)\end{array}$ & $\begin{array}{c}-0.03 \\
(-0.50)\end{array}$ & $\begin{array}{c}-0.05 \\
(-1.60)\end{array}$ & $\begin{array}{c}-0.06^{*} \\
(-1.77)\end{array}$ & $\begin{array}{c}0.002 \\
(0.15)\end{array}$ & $\begin{array}{c}0.13 \\
(1.26)\end{array}$ \\
\hline $\begin{array}{l}\text { Total grants (to all } \\
\text { sectors) }\end{array}$ & & $\begin{array}{l}0.10^{* *} \\
(2.78)\end{array}$ & $\begin{array}{l}-0.03 \\
(-1.64)\end{array}$ & $\begin{array}{c}0.01 \\
(0.58)\end{array}$ & $\begin{array}{r}0.09^{*} \\
(1.67)\end{array}$ & $\begin{array}{l}0.08^{* *} \\
(2.50)\end{array}$ & $\begin{array}{l}0.07^{*} \\
(1.89)\end{array}$ & $\begin{array}{l}0.03^{* *} \\
(2.80)\end{array}$ & $\begin{array}{r}0.12 * \\
(1.80)\end{array}$ \\
\hline $\begin{array}{l}\text { Agriculture as } \\
\text { share of GDP }\end{array}$ & & $\begin{array}{c}0.05 \\
(1.14)\end{array}$ & & & & & & & \\
\hline $\begin{array}{l}\text { Primary school } \\
\text { enrolment rate }\end{array}$ & & & & & & $\begin{array}{c}0.03 \\
(1.17)\end{array}$ & $\begin{array}{r}-0.007 \\
(-0.28)\end{array}$ & & \\
\hline Secondary school & & & & & & -0.06 & $-0.11^{* *}$ & & \\
\hline Enrolment rate $_{t-1}$ & & & & & & $(-1.25)$ & $(-2.42)$ & & \\
\hline $\begin{array}{l}\text { Infant mortality } \\
\text { rate }_{t-1}\end{array}$ & & & & & & & & $\begin{array}{l}0.008^{*} \\
(1.72)\end{array}$ & \\
\hline $\begin{array}{l}\text { Residuals from } \\
\text { domestic } \\
\text { resources } \\
\text { regression }\end{array}$ & & $\begin{array}{l}0.07 * * \\
(6.66)\end{array}$ & $\begin{array}{l}0.01^{* *} \\
(2.50)\end{array}$ & $\begin{array}{l}0.02^{* *} \\
(2.87)\end{array}$ & $\begin{array}{l}0.13^{* *} \\
(7.44)\end{array}$ & $\begin{array}{c}0.14^{* *} \\
(13.19)\end{array}$ & $\begin{array}{c}0.12^{* *} \\
(10.75)\end{array}$ & $\begin{array}{l}0.04 * * \\
(10.46)\end{array}$ & $\begin{array}{l}0.57^{* *} \\
(26.90)\end{array}$ \\
\hline $\begin{array}{l}\text { R-squared } \\
\text { Model }\end{array}$ & $\begin{array}{l}0.22 \\
\text { Fixed }\end{array}$ & $\begin{array}{l}0.20 \\
\text { Random }\end{array}$ & $\begin{array}{c}0.06 \\
\text { Random }\end{array}$ & $\begin{array}{c}0.06 \\
\text { Random }\end{array}$ & $\begin{array}{c}0.23 \\
\text { Random }\end{array}$ & $\begin{array}{c}0.49 \\
\text { Random }\end{array}$ & $\begin{array}{l}0.40 \\
\text { Random }\end{array}$ & $\begin{array}{c}0.36 \\
\text { Random }\end{array}$ & $\begin{array}{c}0.78 \\
\text { Random }\end{array}$ \\
\hline
\end{tabular}

* indicates the same at the 10 percent significance level.

** indicates that a coefficient is statistically different from zero at the 5 percent significance level.

Note: 1 . The large negative coefficient of "concessionary loans to sector" in the education regression is reversed when Botswana is dropped. Botswana is hence an outlier; the analysis in the text focuses on regression (4.7), without Botswana in the sample.

2. Other expenditure is defined as total expenditure less spending on the six sectors. 
Table 5. Estimates for $h_{1,5}$, or the Impact of the Number of Donors On The Level of Fungibility

\begin{tabular}{|c|c|c|c|c|c|c|c|c|}
\hline Dependent variable & Agriculture & Energy & Industry & (5.5) & Education & $\begin{array}{l}\text { (5.7) } \\
\text { Education } \\
\text { without } \\
\text { Botswana }\end{array}$ & Health & Other \\
\hline \multicolumn{9}{|l|}{$\begin{array}{l}\text { Number of donors } \widehat{\theta} \\
\text { concessionary loans } \\
\text { to sector (estimated }\end{array}$} \\
\hline coefficient or $\hat{h}_{1, s}$ ) & $\begin{array}{l}-0.07 \\
(-1.21)\end{array}$ & $\begin{array}{l}-0.02 \\
(-0.69)\end{array}$ & $\begin{array}{c}0.01 \\
(0.44)\end{array}$ & $\begin{array}{l}-0.12^{* *} \\
(-2.39)\end{array}$ & $\begin{array}{l}-0.17 \\
(-0.90)\end{array}$ & $\begin{array}{l}-0.38^{*} \\
(-1.67)\end{array}$ & $\begin{array}{l}-0.36 \\
(-1.34)\end{array}$ & $\begin{array}{l}-0.10 * * \\
(-2.24)\end{array}$ \\
\hline
\end{tabular}




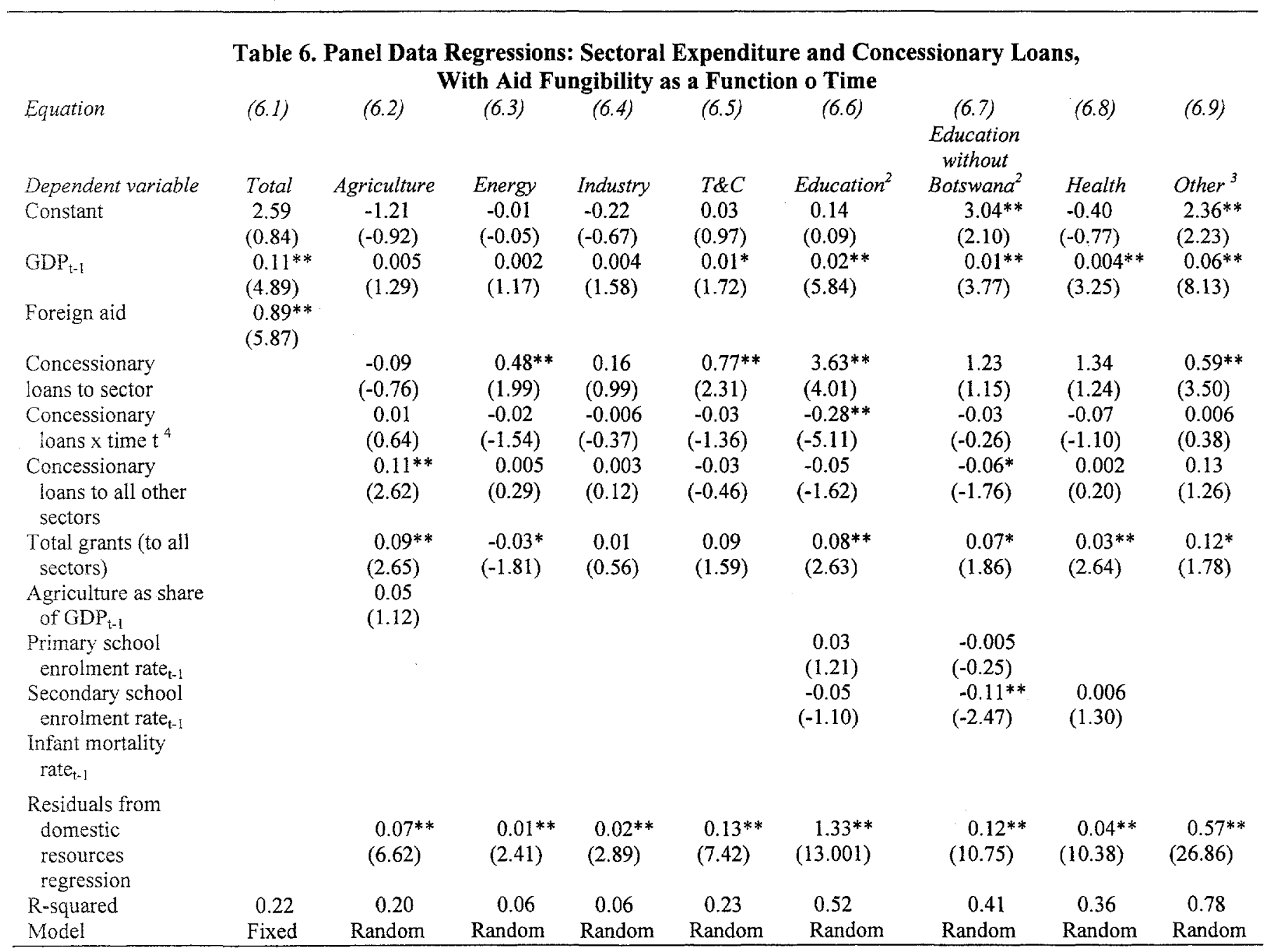

Note: See notes 1 to 3 in table 4.

4. $t$ is an index variable indicating the year. Specifically, $t=1$ for the year 1971 (the first year in the sample), $t=$ 2 for the year 1972, and so on. 


\section{Figure 1}

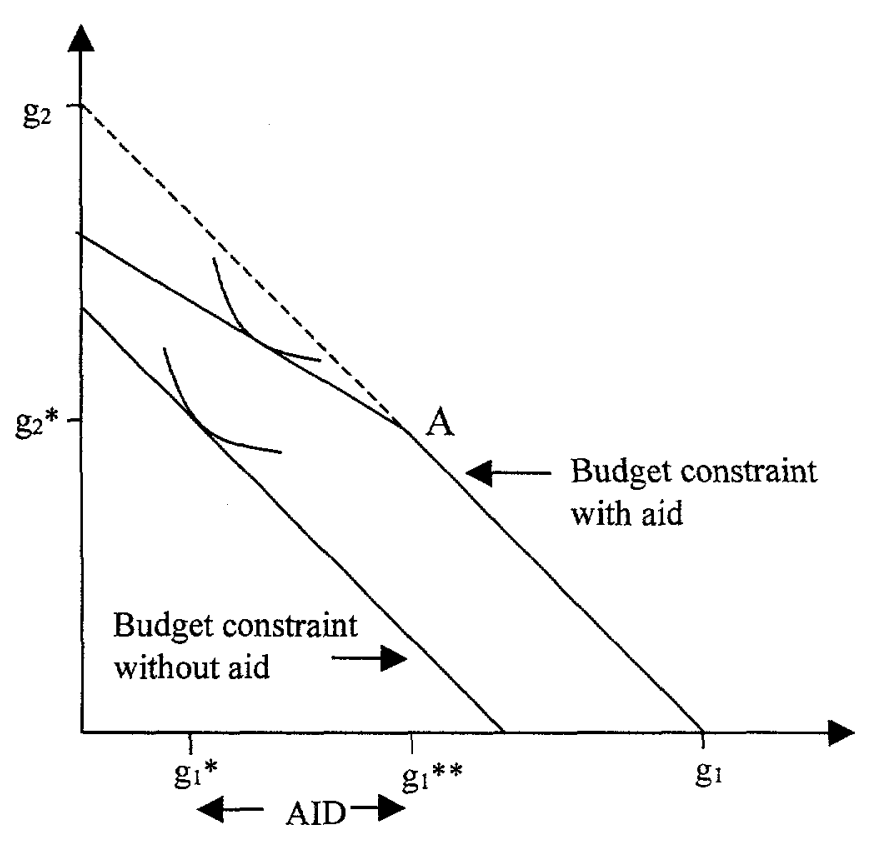

Note: The bold lines and indifference curves illustrate the case where $0<\theta<(\beta-\alpha) / \beta$ (see main text). The dotted line shows the budget constraint if $\theta=0$. Point $A$ is the chosen point if $\theta \geq(\beta-\alpha) / \beta$. 

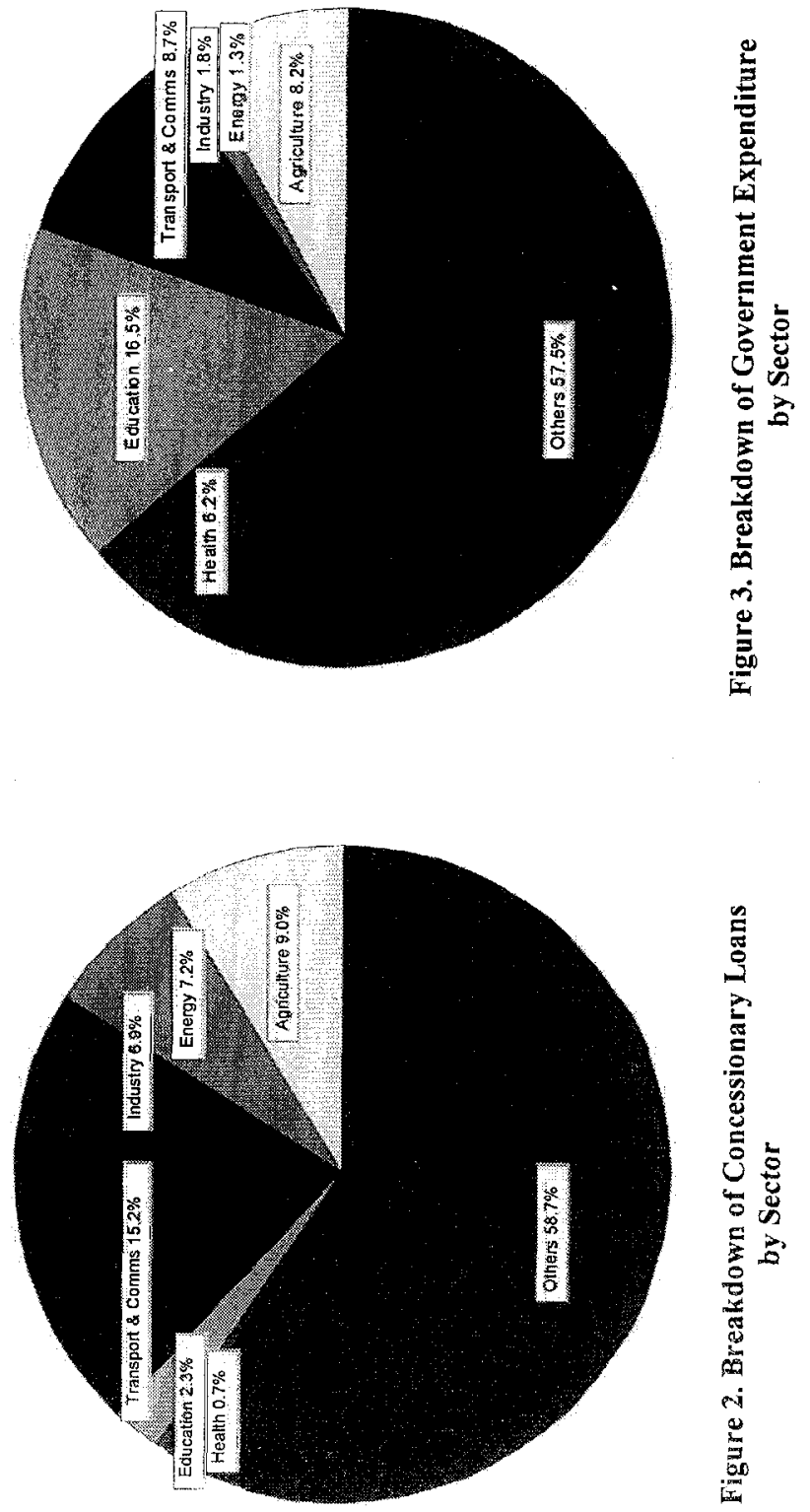
Titie

WPS2072 Growth, Poverty, and Inequality:

A Regional Panel for Bangladesh

WPS2073 Politics, Transaction Costs, and the Design of Regulatory institutions

WPS2074 Light and Lightning at the End of the Public Tunnel: Reiom of the Electrieity Sector in the Southern Cone

WP\$2075 Between Group Inequality and Targeted Transfars

WPS2076 Microdeterminants of Consumption, Poverty, Growth, and inequality in Bangladesh

WPS2077 Change in the Perception of the Poverty Line during Times of Depression: Russia 1993-95

WPS2078 Valuing Mortality Reduction in india: A Study of Compensationg Wage Differentials

WPS2079 Is More Targeting Consistent with Less Spending

WPS2080 Monitoring Targeting Performance When Docentralized Allocations to the Poor Are Unobseme?

WPS2081 Reforming Côte d'voire's Cocoa Marketing and Pricing System

WPS2082 Gross Worker and Job Flows in Transition Economy: An Analysiss of Estonia

WPS2083 INFRISK: A Computer Simulation Approach to Risk Management in Infrastructure Project Finance Transactions
A whtop

Quentin T. Wodon

Antonio Estachs

David Martimort

Antonio Estache Martin Rodriguez-Fardina

Quentin T. Wodon

Quentim T. Wodon

Eranke Milianovic

Branko Jowanowic

Nathalie B. Simon

Maureen L Cropper

Amna Alberini

Seene Aror

Matin Ravalion

Matin Ravallion

Panos Varangis

John $C$. Haltwernger

Minan Vodopive

Miansoor Dailami

Ily Liptoves

John Van Dyok

Mark T. Hol

auenth $\mathrm{i}$. Wodon
Date

March 1898

March 1999

March 1999

March 1999

March 1999

March 1998

Miarch 1989

March $498 \%$

March 1908

March $19 \mathrm{gs}$

Marth 1908

March 196

March 498
Contact

por papa:

ป. Baสami 80425

G. Chengtomith 36370

6. Chenet-smith 36370

\section{Badam} 20425

d. Badami 20425

C. Argayoso 33592

T. Tourougit 87434

P. Sader 33902

P. Sader 33922

P. Kokila 33716

S. Falion 33009

8. Nedrow 31585

C. Anguizola 39232 of Abatement Proposals 
Polley Research Working Paper Serick

\begin{tabular}{|c|c|c|c|c|}
\hline & Title & Mathor & Date & $\begin{array}{l}\text { Gontact } \\
\text { tor paper }\end{array}$ \\
\hline Hos2085 & $\begin{array}{l}\text { Monitoring Banking Sector Fragility: } \\
\text { A Multivariate Logit Approach with } \\
\text { an Application to the 1996-97 } \\
\text { Banking Crises }\end{array}$ & $\begin{array}{l}\text { Asli Demirgügrount } \\
\text { Enrica Detragiache }\end{array}$ & March 1999 & $\begin{array}{l}\text { K. Labrie } \\
\text { 3y } 001\end{array}$ \\
\hline WPS2086 & $\begin{array}{l}\text { Deregulating Technology Transfer } \\
\text { in Agricuture: Reform's Impact } \\
\text { on Turkey in the } 1980 \text { s }\end{array}$ & $\begin{array}{l}\text { David Gisselquist } \\
\text { Can Pray }\end{array}$ & March 1999 & $\begin{array}{l}\text { L. Tabada } \\
36896\end{array}$ \\
\hline WPS2087 & $\begin{array}{l}\text { Male-Fernale Differences in Labor } \\
\text { Market Outcomes during the Early } \\
\text { Transition to Market: The Case of } \\
\text { Estonia and Slovenia }\end{array}$ & $\begin{array}{l}\text { Peter F. Orazem } \\
\text { Milan vodopivec }\end{array}$ & March 1999 & $\begin{array}{l}\text { S. Fallon } \\
38009\end{array}$ \\
\hline WPS 2088 & $\begin{array}{l}\text { Expropriation of Minority } \\
\text { Shareholders: Evidence from } \\
\text { East Asia }\end{array}$ & $\begin{array}{l}\text { Stijn Claessens } \\
\text { Sirnean Djankov } \\
\text { Joseph P. H. Fan } \\
\text { Larry H. P. Lang }\end{array}$ & March 1999 & $\begin{array}{l}\text { R. Vo } \\
33722\end{array}$ \\
\hline WP52089 & $\begin{array}{l}\text { Corporate Diversification in East Asta: } \\
\text { The Role of Ultimate Ownership and } \\
\text { Group Affilication }\end{array}$ & $\begin{array}{l}\text { Stin Claessens } \\
\text { Simeon Diankov } \\
\text { Joseph P. H. Fan } \\
\text { Larry H. P. Lang }\end{array}$ & March 1999 & $\begin{array}{l}\text { R. Vo } \\
33722\end{array}$ \\
\hline WPS2080 & $\begin{array}{l}\text { Risks, Lessons Learned, and } \\
\text { Secondary Markets for Greenhouse } \\
\text { Gas Reductions }\end{array}$ & $\begin{array}{l}\text { Donaid F. Larson } \\
\text { Paul Parks }\end{array}$ & March 1999 & $\begin{array}{l}\text { P. Kokila } \\
33716\end{array}$ \\
\hline NPS2091 & $\begin{array}{l}\text { Beyond Unequal Development: } \\
\text { An Oyerview }\end{array}$ & Andrés Solimano & March 1999 & $\begin{array}{l}\text { A. Solimano } \\
87671\end{array}$ \\
\hline
\end{tabular}

